\title{
Incarnating and articulating the female other. Interview with Helena Walsh
}

Christelle Serée-Chaussinand and Helena Walsh

\section{(2) OpenEdition \\ 1 Journals}

\section{Electronic version}

URL: http://journals.openedition.org/etudesirlandaises/5544

DOI: 10.4000/etudesirlandaises. 5544

ISSN: 2259-8863

\section{Publisher}

Presses universitaires de Caen

\section{Printed version}

Date of publication: 30 May 2018

ISBN: 978-2-7535-7578-3

ISSN: 0183-973X

\section{Electronic reference}

Christelle Serée-Chaussinand and Helena Walsh, «Incarnating and articulating the female other. Interview with Helena Walsh », Études irlandaises [Online], 43-1 | 2018, Online since 30 May 2018, connection on 15 September 2019. URL : http://journals.openedition.org/etudesirlandaises/5544 ; DOI : 10.4000/etudesirlandaises.5544

This text was automatically generated on 15 September 2019.

(c) Presses universitaires de Rennes 


\title{
Incarnating and articulating the female other. Interview with Helena Walsh
}

\author{
Christelle Serée-Chaussinand and Helena Walsh
}

You are Irish you say lightly, and allocated to you are the tendencies to be wild, wanton, drunk, superstitious, unreliable, backward, toadying and prone to fits, whereas you know that in fact a whole entourage of ghosts resides in you, ghosts with whom the inner rapport is as frequent, as perplexing, as defiant as with any of the living ${ }^{1}$. Edna O'Brien, Mother Ireland, 1976. I need to bear witness to an uncertain event. I feel it roaring inside of me - this thing that may not have taken place. I don't even know what name to put on it. I think you might call it a crime of the flesh, but the flesh is long fallen away and I am not sure what hurt may linger in my bones². Anne Enright, The Gathering, 2007.

CHRISTELLE SERÉE-CHAUSSINAND (csc) - Your practice as a live artist for fifteen years has had the female body as its central motif. From "Passageway" or "Invisible Stains" to "Tricolour" or "Body Mist", the female body is staged in relation to history, societal expectations and gendered norms to explore identity, motherhood, domesticity, sexuality, etc. What do you aim to expose exactly?

Helena Walsh (HW) - My aim is to expose gender constructs as central to Irish national identity, to interrogate and subvert the ideals of femininity and nationhood as reflected in the symbolic appropriation of the female body within Irish nationalist iconography. Live Art is a particularly valid medium for countering the ways in which patriarchal ideologies negate the actualities of female experience and limit women's political agency. Lois Keidan, Director of the Live Art Development Agency, London outlines the 
importance of Live Art practices in constructing 'new strategies for the expression of identities', and making the 'disenfranchised and disembodied' visible ${ }^{3}$. In using my body and self, I try to open up the possibilities for developing more empowered expressions of identity that might usefully contribute to emergent feminist discourses across the field of performance in Ireland. O'Brien and Enright cited above present Irish culture as endlessly haunted by the ceaseless chattering of 'ghosts' or the 'roaring' of uncertain, unnameable memories. In my practice, I hope to ground the spectral or the unknowable in the body, to incarnate that which is at once vague and ethereal, yet loudly persistent.

csc - Do you think that this attempt to lodge the spectral and the unnamed inside the body is emblematic of Live Art?

HW - Yes, I certainly do think that Live Art and performance can be usefully deployed to express that which is unnamed, for example, the impact of unspoken societal norms on the body or those experiences negated from dominant discourse. In her book Performing Remains: Art and War in Times of Theatrical Reenactment (2011), Rebecca Schneider notes that "performance plays the "sedimented acts" and spectral meanings that haunt material in constant collective interaction, in constellation, in transmutation'4. She suggests:

As theories of trauma and repetition might also instruct us, it is not presence that appears in performance in the syncopated time of citational performance but precisely (again) the missed encounter - the reverberations of the overlooked, the missed, the repressed, the seemingly forgotten ${ }^{5}$.

In using their bodies to interrogate women's histories live artists retrieve 'the overlooked, the missed, the repressed, the seemingly forgotten' ${ }^{6}$. Importantly, Schneider locates the body, or more specifically flesh, as the place of performance's remains and as that which enables a questioning of the logic of the archive. She asserts that 'the place of residue is arguably flesh in a network of body-to-body transmission of affect and enactment - evidence, across generations, of impact'7. As Schneider observes, 'flesh, that slippery feminine subcutaneousness, is the tyrannical and oily, invisible-inked signature of the living. Flesh of my flesh of my flesh repeats, even as flesh is that which the archive presumes does not remain's. In using their bodies to retrieve and activate that which is concealed by 'the logic of the archive' female live artists contribute to contemporary feminist discourse. Likewise, they challenge ongoing gender oppressions by "digging" role models from the past. In doing so, they operate against the silencing of women's histories and establishing new roles for women today and in the future.

csc - Is the female body still an alienated body? Would you say there is still a long way to go before women re-appropriate their bodies?

HW - Despite progressive shifts - decriminalisation of homosexuality in 1993, lifting of restrictions on the availability of contraception in 1994 and legalisation of divorce in the Republic of Ireland in 1995, alongside the recent legalising of same-sex marriage by popular vote in 2015 - women's bodies remain constrained by a set of restrictive laws and considerably outdated patriarchal norms. As the remaining ban on abortion in both Northern Ireland and the Republic of Ireland make clear, motherhood is overtly essentialised across the island of Ireland. While England, Scotland and Wales clarified the circumstances in which abortion is permissible under the Abortion Act 1967, Northern Ireland remained exempt from this legislation. The 1861 Offences Against the 
Persons Act, which carries a sentence of life imprisonment for those who have an abortion illegally, is still in place there. Whereas, in the Republic of Ireland the $19838^{\text {th }}$ Amendment to the Irish constitution legislated that the fetus from conception has the same equal rights to life as the mother. This restricts abortion unless there is a risk to the life of the mother. As Ruth Fletcher asserts, this demonstrates that 'the control of women's fertility is symbolically and materially important to several different species of nationalism in the region: Irish postcolonial conservatism, Irish anti-colonial republicanism and British unionism's. However, a large and vocal pro-choice movement has developed an increasing presence across the island in recent years, paving the way for a referendum on the $8^{\text {th }}$ Amendment in the Republic of Ireland in 2018.

csc - Which of your works does particularly address this control of women's sexuality and fertility?

HW - My work Invisible Stains (2010) addressed the containment of women's sexuality and the control of fertility. It was performed in Kilmainham Gaol, Dublin, the historic prison in which leaders of the 1916 Rising were executed that now operates as a museum of nationalist history. This performance explored the injustices experienced by the women that were incarcerated in Magdalen Laundries, state-sanctioned Catholic convents, which ran for-profit industrial laundries. Women, deemed to have upset societal norms of moral purity, such as unmarried mothers, or women unwanted by society, were detained in these punitive institutions and forced to work unwaged in the laundries. The last Magdalen Laundry closed in 1996. My actions and the materials I used in the performance referenced the labours and losses experienced by the women of the Magdalen Laundries, in an effort to countering the disavowal of their experiences and the punitive patriarchal systems that seek to contain female sexuality. At the time I made this performance the women incarcerated in these institutions were battling for state redress. In 2013, following the publication of the McAleese Report, the Irish government apologised for its complicity in sustaining the Laundries. However, this report omitted 796 pages of testimonies by women who were detained in Ireland's Magdalen Laundries, gathered by the campaign group Justice for Magdalenes and downplayed the human rights abuses suffered. Equally the Catholic orders that ran the laundries refused to contribute to the redress scheme.

During the performance my breasts were bound tightly with bandage, a reference to use of breast binding in the Laundries to maintain modesty. I wore a long skirt made up of blue and white baby-gro suits (all-in-one baby suits). This was held together by clothes pegs with a band of blue pegs spiked around my waist, while my hands were gloved with 'Madonna' blue marigolds. Throughout the four-hour performance I repetitiously performed a number of tasks. For instance, I poured laundry powder onto the floor of a prison cell and on un-pegging one of the baby-gros from my skirt, I scooped the washing powder into the baby-gro until it resembled human form, becoming a pretend 'baby.' The constructing of a 'baby' from washing power references the loss experienced by some women of the Magdalen Laundries who were forcibly separated from their children. Writing of witnessing this action Magdalena Maria Wieckiewicz, noted that 'in this epitome of motherly love and tenderness, there is also a tincture of sadness and pain. As [Walsh] fills up the playsuit with washing powder, the obscure gesture becomes difficult to watch ${ }^{10}$. Her observations demonstrate, perhaps, the ways in which performance can make the, often silenced, actualities of women's experience felt. 
Walking around the prison, with great care I cradled, rocked and stroked each of the fake babies I constructed over the course of the performance. However, my pretence was eventually dropped as each 'baby' was repeatedly dipped into a large blue bucket of water, causing the washing powder inside the baby-gro to foam up and fizz in the water. This action evoked not only the labours of the women in the Magdalen Laundries but also the designation of women to the role of endless reproduction and domestic duties. After each 'baby' was dunked in the bucket, the fabric was then stretched out so that all the washing powder became squeezed into two ball shapes, from which two white streams of watery washing powder ran, similar to milk from breasts, which contrasted with my bound breasts. When it ran dry the fabric was reshaped to resemble a penis. Through the top of each cloth phallus an S-hook was pierced. Over the course of the four-hour performance ten of these phallic shapes were hung on the central staircase in Kilmainham, dialoguing with the commemoration of the 1916 martyrs on this site, while offering a retort to patriarchal systems of containment that seek to enslave women and restrict their reproductive agency.

Helena Walsh, Invisible Stains, 2010, in “Right Here, Right Now”, Kilmainham Gaol, Dublin

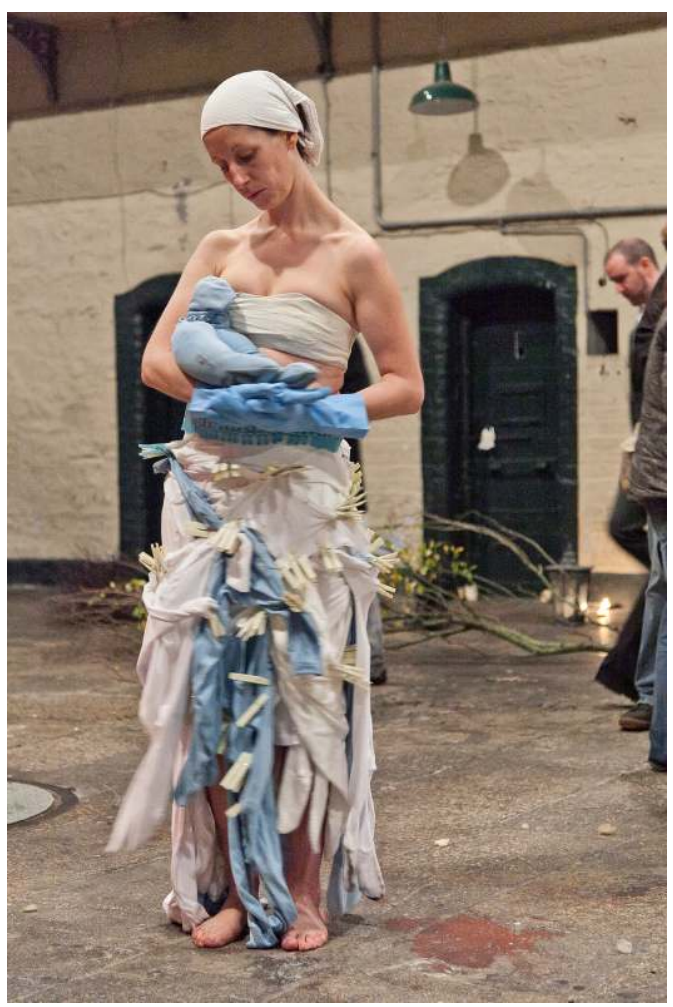

Photo Joseph Carr. 


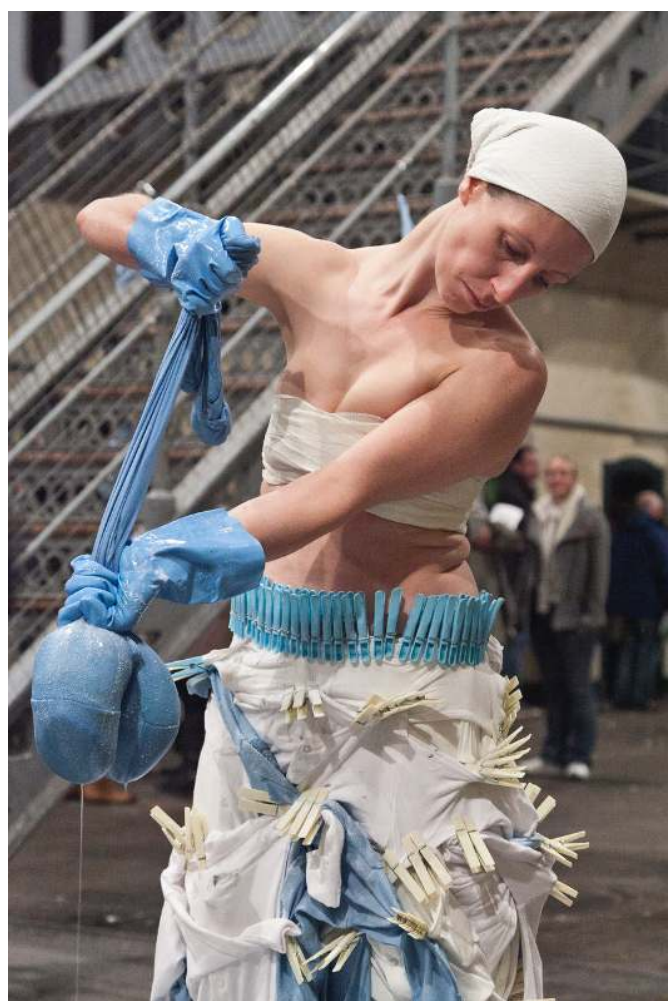

Photo Joseph Carr.

csc - Do you believe that nationalist iconography similarly contributes to trivialise and potentially erase women's contribution to national independence?

HW - In fact we need to be mindful of the deep entanglements that stem from the representation of women's bodies as symbolic of the nation within nationalist iconography. As Kathleen M. Gough observes, nationalist iconography enables women visibility only within the confines of patriarchal ideologies: 'Cathleen Ní Houlihan works by way of discrete disappearances. In other words, when the call to Cathleen (nationalism) is heralded, "real" women seem to vanish'11. Exemplifying this, Margaret Kelleher highlights that Gonne's 'famine writings display the actions of a pragmatic and politically astute woman' and 'this is an aspect of her personality frequently obscured by the more mythical dimension of Gonne as Cathleen' ${ }^{12}$. Similarly, in an article that calls for a feminist analysis of the functioning of male martyrdom within the Irish insurrection, Mary Condren highlights 'the establishment of patrilineal structures, which are a social rather than a biological achievement'13. Such 'patrilineal structures' enabled the 'discrete' erasure of the women who participated in the 1916 Rising from dominant historical narratives throughout the twentieth century. However, women were very active, participating in the fighting as members of both Cumann na mBan and the Citizen Army, or acting as couriers, fund-raisers, gun-runners, cooks and tending to the wounded ${ }^{14}$. As well as their commitment to national independence, many revolutionary women were committed socialists and feminists who championed gender equality and women's involvement in politics.

If the women revolutionaries who participated in the Rising transcended the gender norms of the time, the state authorities, which emerged following the partition of 
Ireland and an embittered Civil War (1922-1923), wasted no time in returning women to a primary role within the home and were it not for the work of feminist historians women's involvement in the Rising would be all but forgotten. With the Catholic Church's grasping of power over social policy, women's rights were eroded at a steady pace as the southern state trundled towards becoming a Republic in 1949. Referring to the Civil Service Act (1956), commonly known as the 'marriage bar,' which required that women working in the Civil Service resigned on marriage, Frances Gardiner observes 'almost four decades of increasingly authoritarian legislation, which curbed women's self-determination to the extent that political involvement was severely curtailed, if not actually impossible, for most women, save as political wife, sister or mother ${ }^{115}$.

The resignation of women to the duties of motherhood and the home remains inscribed in Article 41.2 of the 1937 Irish constitution, which states that 'in particular, the State recognises that by her life within the home, woman gives to the State a support without which the common good cannot be achieved ${ }^{16}$. The combined submissive serenity of the self-sacrificing and nurturing Mother Ireland and the passive sexuality of the virginal Catholic Madonna spearheaded the state's legislative efforts to limit women to the duties of reproduction and domesticity. As Fintan Walsh notes, 'while Irish manhood may have been cursed by impotency within a colonial imaginary, Irish womanhood was shaped by restrictive norms measured against the Virgin Mary, Mother Ireland and Eamon de Valera's fantasy of happy maidens ${ }^{117}$.

csc - In "Autonomy"18, the durational and site-responsive performance you made in Kilmainham Gaol for 'Future Histories' in 2016, your body is the meeting point of the military and the domestic, the political and the bucolic and is turned into a tool of political expression. On which material did you draw and how did you invest yourself in the performance?

HW - The performance drew inspiration from accounts of the activities of revolutionary women retrieved by feminist scholars, including the political writings of revolutionary women themselves in such publications as Bean na h-Éireann (1908-1911) and the suffrage publication, The Irish Citizen (1912-1920). One key inspiration is the subversion of domesticity within the regular gardening column titled "Woman with a Garden" which was featured in Bean na h-Éireann. The author of the gardening section is disputed as many authors concealed their identities with Gaelic pseudonyms. Some suggest this section was penned by Maud Gonne, others maintain it was by Countess Constance Markievicz ${ }^{19}$, Steele, who attributes these writings to Markievicz, discusses how the gardening section was rife with allegorical descriptions. For example, 'mature blossoms, such as summer roses, recalled Roisin Dubh, as well as the blood of martyred United Irishmen (July 1909)' ${ }^{20}$. Within the section 'the garden's enemies - slugs, snails, wasps, flies - were viewed as British Soldiers, invaders that destroyed the flowers and fruits of the land' and 'destructive "forces of the earth" such as heavy frost, cruel blights, bitter gales and blinding snow, were predictably associated with the British Empire or its symbolic presence in Dublin Castle ${ }^{21}$. The column also used garden allegory to recall past nationalists heroes. For example, the author used reference to lavender to recall Robert Emmet's love of the plant and refer to the confiscation of a sprig of lavender handed to him in court during his trial lest it be used to conceal poison. Steele also highlights the criticisms of the gardening section, detailing that Innes views 'the "startling" transitions between revolution and roses' as evidence of the authors' 'rhetorical entrapment between the nationalist discourse of warriorhood 
and stereotyped feminization'22. In my performance, however, I purposefully sought to play with the imagery evoked in the gardening section to draw out these tensions between nationalism and feminism.

Helena Walsh, Autonomy, 2016, in "Future Histories", Kilmainham Gaol, Dublin

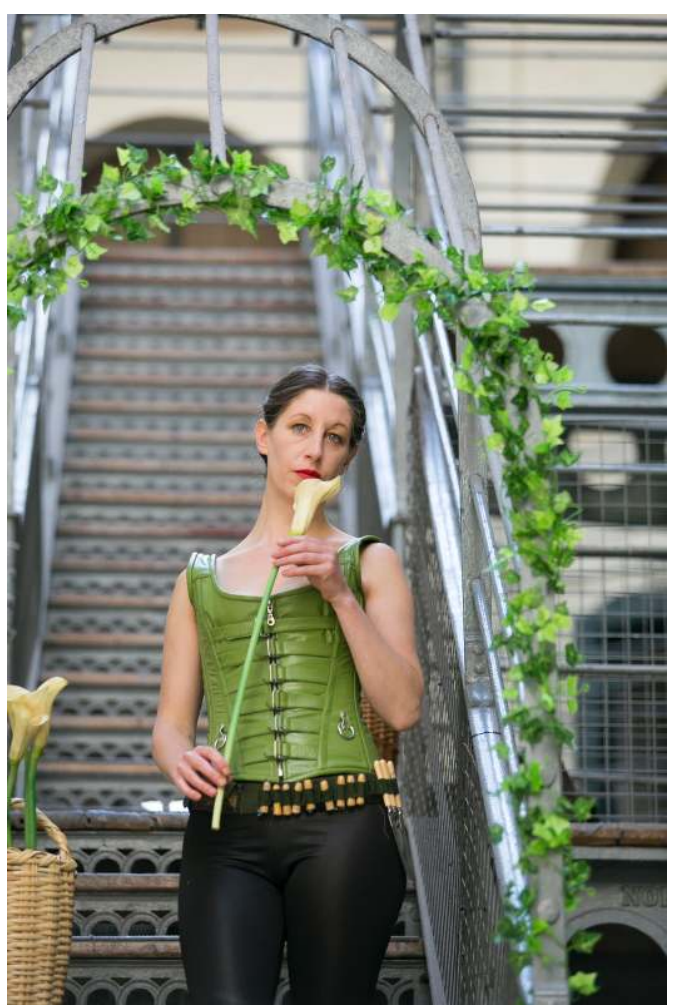

Photo: Joseph Carr. 


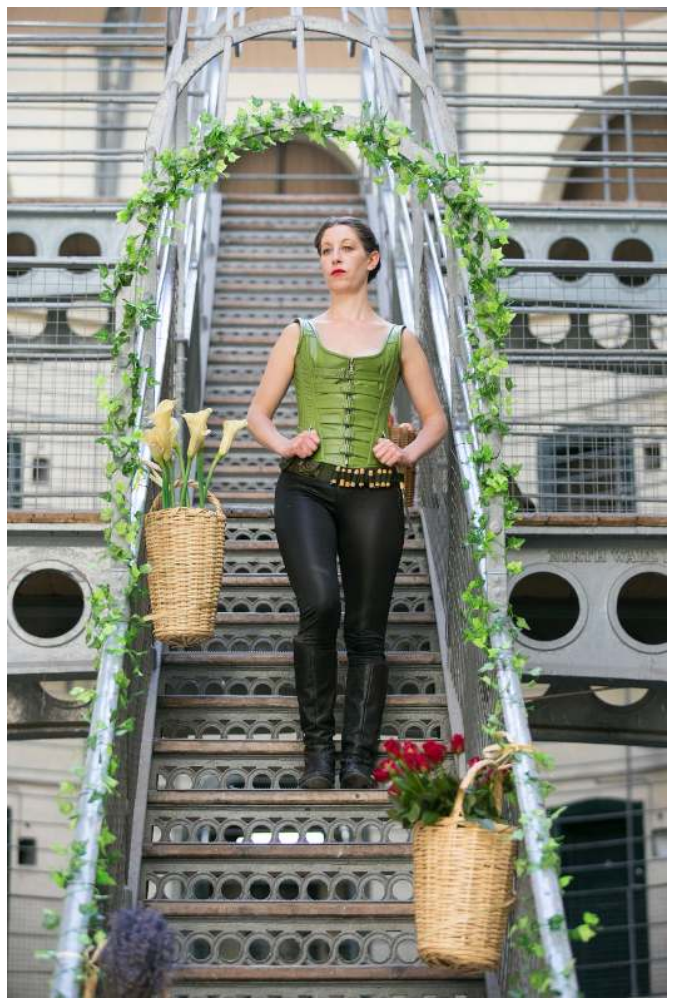

Photo: Joseph Carr.

During the performance I took up residency on the central staircase of the East Wing of Kilmainham Gaol, dressed in an outfit that merged early twentieth century modesty with a warrior-type aesthetic, which comprised of a green leather corset, shiny black leggings, a long dark green suede coat, which one of the tour guides remarked looked like an authentic relic of 1916. I also wore an army belt containing butter-knives and gold-sprayed tampons around my waist. The arch of the staircase was decorated with plastic ivy. A number of baskets, which were positioned around the staircase contained apples, lavender, roses and white rubber lilies. The 'tackiness' of some of my materials, such as the plastic ivy, made for a purposefully cheapened-looking 'nationalist garden.' During the performance I spent my time dismantling this 'nationalist garden.' I peeled apples and flicked the skins at members of the audience and those participating on the official prison tours, which trailed through the space persistently throughout the day, flinging the skinned apples from the top of the stairs. I crushed the lavender between my fingers releasing its aroma before blowing it towards viewers. I beheaded individual roses and sitting on the staircase, held each rose head to my crotch, fingering it so that it opened up and the rose petals fell from between my spread legs, making a red stained pathway down the staircase. Outlining the fight for reproductive autonomy as an ongoing contemporary battle, at other times, I inserted the gold-sprayed tampons, reminiscent of bullets, inside a rubber lily, as if it were a replacement stamen. The lilies, of course, drew on the iconography of the Easter Lilly used to commemorate the Rising. On pulling back the lily head, making use of the elasticity of the rubber stalk, I hurled tampons across the prison. Throughout, I eyeballed the audience, both those intending to see the performance and those on the tours, with what one audience member 
described as my 'panoptical gaze.' Over the course of the ten hours I performed in 'Future Histories', I developed a connection, of sorts, to the women revolutionaries of 1916 that were once imprisoned in the gaol. As the performance progressed my actions became emboldened and inspired by an embodiment of the sense of the threat these women posed to the patriarchal ideologies of the foundling Irish state, which the state authorities sought to fervently repress. This embodying of a threatening presence, I might add, was a thoroughly enjoyable communing with history.

csc - Did other female live artists involved in 'Future Histories' at Kilmainham aim to reflect the same loss of voice and subjecthood, the same subjugation of women?

HW - At the same time as I embarked on giving body to a threatening female force, another of the Live Artists performing in the event, Katherine Nolan, explored 'the embodiment of the Irish nation as woman ${ }^{23}$. Entering the space on the hour throughout the day, Nolan vocalized a woeful wailing and breathlessness that heightened in tension and rapidity as she moved around the East Wing with an ever-increasing pace. She would then vanish only to return to 'haunt' the site again at a later point. Nolan states that her mournful melodramatics sought to evoke the haunting presence of 'mythical figures' such Cathleen Ni Houlihan in response to 'the Gaol as site of trauma and loss', yet equally 'the repression of women's full access to subject-hood in Irish society, lore and law'24. Indeed, Nolan's embodying of the sorrowful figure of Cathleen was loudly declared and she had a solid presence in the space demonstrating the deployment of the body in live art to deprive the haunting, idealized representations of women central to Irish nationalist iconography of their power to vanish real women.

csc - Flouting the conventions of the female nude and self-portraiture, you repeatedly expose your naked body in your works. Neither idealised nor aestheticized, your performative body is a deliberately organic, sentient and erotic body. How does it become a locus of resistance?

HW - Just as the canon of art is populated with idealised imagery of the female nude, contemporary Western visual culture is saturated in imagery of airbrushed, predominantly white, female bodies that conform to hetero-normative, patriarchal desires. Alongside objectifying women, such images negatively impact on women and young girls by making them feel as if their real bodies are somehow inherently flawed or that they have to look and behave in a certain way in order to be acceptable or desirable. In exposing my naked body in my work, I attempt to counter this by confronting audiences with the actualities of the female body, its fluids, its abject functions, its everydayness. Yet, given the pervasiveness of patriarchal imagery and norms, countering oppressive gender constructs is not an easy or simple task. Relevant to this, my work explores the subjugation and vulnerabilities of the female body, while simultaneously attempting to develop more empowered expressions that counter patriarchal ideals. I find that durational performance, in particular, allows a space in which the difficulties inherent in countering idealised images and patriarchal norms can be exposed, while the possibilities for pushing the expressive potentials of the female body towards the development of more empowered gestures can be organically opened up overtime. Within my durational performances, I often explore histories of oppression and work through repressive patriarchal imagery or constructs that serve to impose a particular set of behaviours. I attempt to dismantle this imagery, while simultaneously working towards the development of gestures that positively trouble patriarchal ideals and contribute to the development of feminist discourses. As such, within durational performance I engage in the often slow, often tiring and often 
repetitive labour of undermining long-ingrained patriarchal constructs of their oppressive power. This sometimes involves the deployment of the erotic body in a subversive manner. For me, perhaps, it is within this process of interrogating the subjugation of the female body (both historic and present), while simultaneously attempting to counter oppressive patriarchal constructs and twist towards the development of more empowered expressions that the performative body becomes a locus of resistance.

csc - The piece you performed at the Atheneum, Dijon, in 2013 is a perfect example of your exposed body as locus of resistance, isn't it? Tell us about this piece.

HW - My performance in the Atheneum Theatre, Dijon used the abject body to directly confront the 'sanitised images of woman as muse and woman as nation' ${ }^{25}$. The performance was developed from the work resultant from my participation in LABOUR, a touring group durational exhibition featuring eleven female artists resident within, or native to, the Republic of Ireland and Northern Ireland, which was co-curated by Amanda Coogan, Chrissie Cadman and myself. In response to the theme of 'Irish selfportraiture' I sought to positively violate the positioning of the female body as representative of the Irish nation. Parodying the iconography of the Virgin Mary and the proverbial Mother Ireland, I wore a gold-embossed pale blue dress and a goldsprayed balaclava, rolled up to reveal my face; the balaclava had numerous knitting needles spiked through its top resembling perhaps a crown of thorns or the halos. Around my waist I wore two army belts. Baby bottles containing a mixture of menstrual blood and milk were attached to one belt. The other contained pouches of Catholic altar bread or Holy Communion. The row of baby bottles circling my waist, which looked like a bullet belt, alongside the balaclava endowed my appearance with a sense of militancy, which referenced the territorial control of female reproductive autonomy.

Helena Walsh, In Pursuit of Pleasure, 2012, in “Labour", Void Gallery Derry / Londonderry

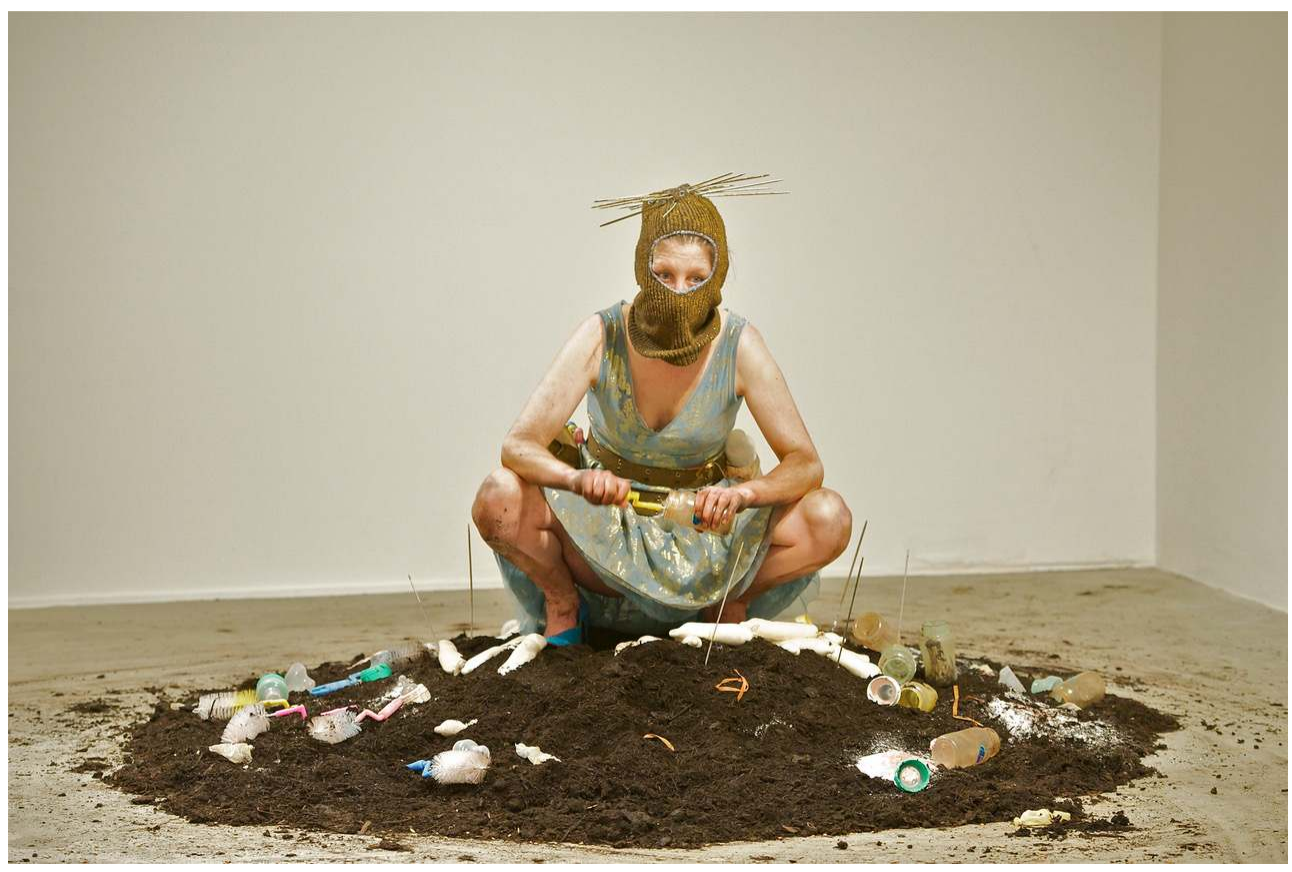

Photo: Jordan Hutchings. 
At the beginning of the performance, I stood on a circular bed of soil, covered in a circle of condoms, which were filled with washing powder, hence, taking on a phallic shape. The laundry powder referenced the enslavement of women in the Magdalen Laundries and, in turn, the moral regulation of women. With my arms held outstretched I parodied the pose of the Virgin Mary, tilting my head and looking serenely at the audience. As a soundtrack played the Irish national anthem, I pulled a rolled up Tricolour (the Irish flag) from my vagina and placed it over the bed of soil. This action, on the one hand, made explicit the alignment of women's bodies as representative of the nation, and equally the resigning of women to the duties of motherhood, breeding and nurturing the new nation. On the other hand, it also upset the ways in which, as outlined by Mary Condren, martyrdom enables men to lay claim to the birth of the new nation (gendered as female) and establish patriarchal systems of power based on a sacrificial social contract. As Condren notes this produces a 'return to the pre-Oedipal mother issues in a final act of patriarchal reversal where the warrior now gives birth to the mother rather than she to him ${ }^{26}$. This action of giving birth to the national flag then, perhaps, troubled the privileging of martyred male bones, which is dependent upon the disappearance of female genealogies.

As the performance progressed, and the Irish anthem became increasingly distorted and mechanical sounding, I marched around the space, balaclava down. At intervals I defiled the flag by dripping the mixture contained in the baby bottles on it. I also inserted one of the laundry-filled condoms inside my vagina, taking one of the knitting needles from the balaclava on my head and using it to pierce the condom so that the white washing powder sprayed out onto the soil, parodying of a man pissing and, in turn, undertaking a territorial marking of the soil. To add to my purposeful irreverence, at times, I crumbled the Holy Communion wafers onto the floor and at other times, chewed it, spitting the soggy bread toward the audience. As the odour of the laundry powder, soil and the rancid smell of menstrual blood and milk permeated the air, the realities and actualities of women's reproductive bodies and maternal labour, in all its messy, leaky glory entered the atmosphere. This unleashing of the threatening or destabilising potentials of the female body in the performance enabled, perhaps, an undoing of the sanctified, patriarchal versions of femininity that have perpetuated the systematic punishment of women in institutions such as the Magdalen Laundries. 


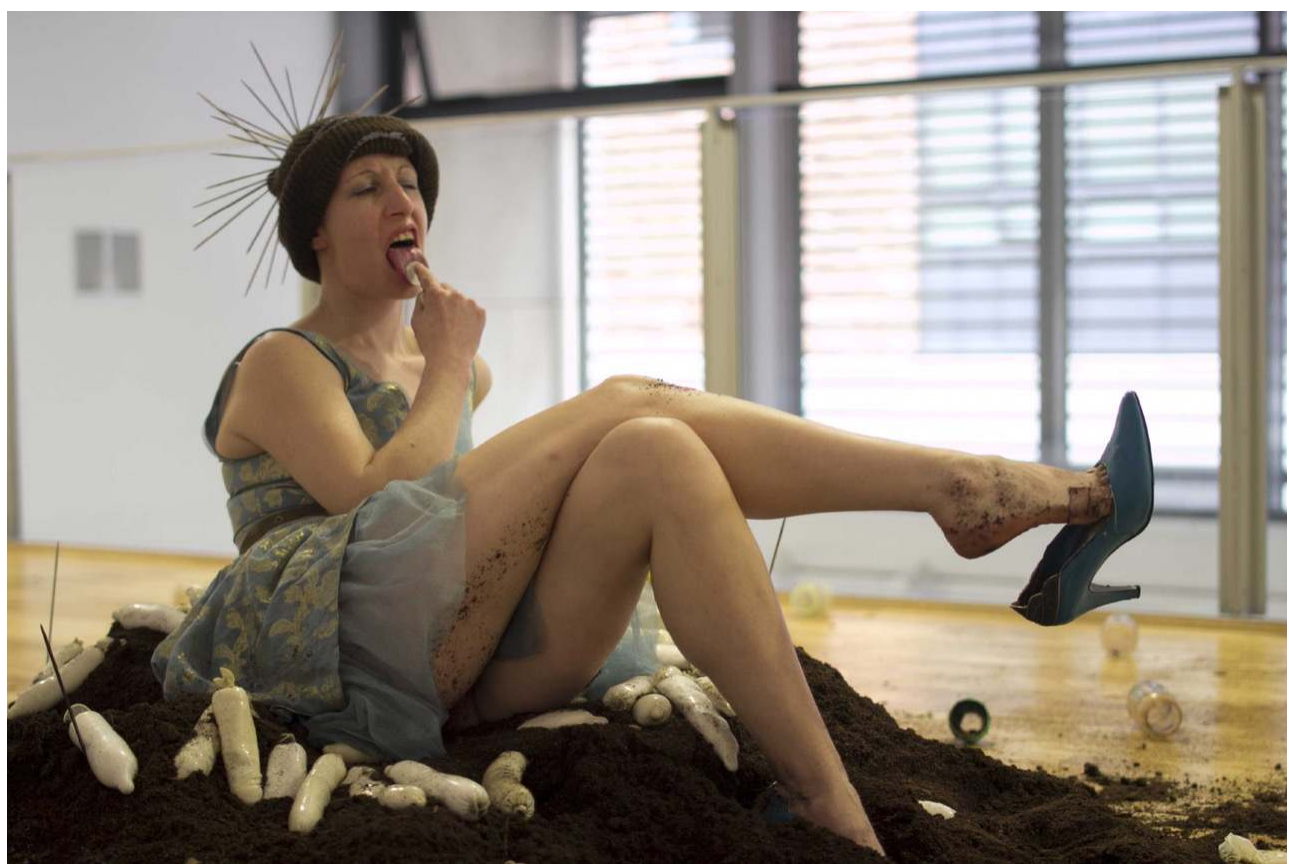

Photo: Jordan Hutchings

csc - How much do you draw on your own experiences in your works?

HW - My work has always been influenced by my lived and embodied experiences. For instance, my early works were very much inspired by the experience of coming of age and challenging the social pressures that young women live through to conform to patriarchal ideals of beauty. Later works, such as the aforementioned Invisible Stains, were informed by my experience of motherhood, which led to an interrogation of the policing of pregnant bodies and reproductive autonomy. Hence, while my works are informed by personal experiences, I explore these experiences in relation to broader social, political, cultural and historical contexts. In turn, the responses to my work also enable understandings around how the female body is perceived within specific contexts. For example, judging by the responses of the audiences, Food for Thought (2001) proved acutely revealing as to the ways in which the female body is central to ideals of nationhood. This work was a personal response to my teenage experience of Anorexia Nervosa - an eating disorder characterised by self-starvation that I succumbed to in the midst of the Celtic Tiger era, as the overt consumerist commodification of women's bodies in accordance to homogenized Western ideals of beauty became increasingly present in an Irish cultural context.

Food for Thought constituted a simple, yet deeply personal, self-portrait of this experience. As part of this video performance I covered my body in a mixture of spring roll pastry and latex, lighting the set in such a manner that the false layers of skin applied to my body were not readily noticeable and the skin of my naked body appeared unblemished. Sat on a stool, I scratched at the latex, peeling, picking and at times ripping it off my skin. I also binged voraciously on what appeared to be my own flesh by flaking off the spring roll pastry, gathering clumps of it in my hands and shoving it into my mouth. Lifting my foot to my mouth I gnawed on it and ripped layers of 'skin' from my breast or knee with my teeth. The action of pulling 'flesh' from my 
body was over-layered with harsh ripping sounds, made through tearing paper. Visualising the notion that following prolonged reduction in food consumption, relating to anorexia, the body begins to consume itself, the performance staged the driven yet destructive aspects of my teenage self-starvation.

This video was exhibited with a number of my other works focused on critiquing the pressure placed on young women to conform to Western ideals of beauty. This included another video performance titled Body Mist, which explored how the expanse of beauty products for female aesthetic improvement may make women feel as if every area of their actual bodies requires a form of erasure. Throughout this performance I covered myself from head to foot in cosmetic products. On the video documentation following each aesthetic improvement or the application of each product, the part of my body attended to darkens, then fades and eventually becomes transparent, until all that remains of my body is a ghostly outline. To achieve this effect I used what is technically termed a 'green screen.' Both videos were exhibited in The Real Art Space, a gallery located in a two-storey townhouse in Limerick city. Drawing on the inherent domesticity of this site the videos were installed in the upstairs bedrooms. Audience members watched the videos by peering through the peepholes of the closed door to each bedroom. The looped videos were projected onto the bedroom walls so that the projection was reflected in strategically placed mirrors, making further ghostly my vanishing or diminishing flesh.

These works play with what Rebecca Schneider in her book, The Explicit Body in Performance (1997), details as a habituation 'to watching a secret' in a society where 'the feminine' is 'emblematic of the private sphere'27. In performing the erasure of my naked body the videos interrupted this system of voyeuristic viewing in that the more the viewers watched the less they saw. When playing in loop, however, the videos showed a cycle of disappearing female flesh, bodies being erased or consumed only to reappear whole again: this relates to Schneider's positioning of woman as 'emblem of consumptive desire and designated capitalist consumer, [who] sets out to consume herself in an anorectic frenzy of the logic of the vanishing point - attempting to consume her own inaccessible image, chasing after disappearance infinitively ${ }^{28}$.

csc - How did the audience understand this performance?

HW - Despite the framing of this exhibition as a body of work concerned with the sanitising effects of the 'beauty myth' in a contemporary Western context, a considerable quantity of the audience located this exhibition as relevant to Irish cultural histories. Many audience members related Food for Thought, in particular, to the Great Irish Famine (1845-1851), the Catholic ritual of Holy Communion and the 1981 republican hunger strikes in the H-Block Prison, Belfast.

In retrospect, perhaps, my feasting on my own flesh relates to the consumption of the 'Body of Christ' within the Catholic ritual of Holy Communion. Perhaps, my animal-like savagery also relates to the use of female imagery to represent the Famine. As outlined by Kelleher, 'the recurrence of female images in representations of the Famine (...) enables the Famine's narration'29.

The reflections of my fading female body in mirrors, which sought to evoke my personal experience were, albeit inadvertently, ghosted with historical perspectives central to the Irish nationalist archive. The responses to this early work demonstrate how deeply intertwined female bodies are with the ideals of nationhood in an Irish 
context and how such operates to negate the actuality of women's experience. Yet, these works equally outline how the use of the explicit body can expose what Schneider outlines as 'the paradigm of perspective, as a historical habituation to any scene ${ }^{\prime 30}$. Noting the gendering of perspective, Schneider claims 'the scopic field is riddled with desire,' to which the disembodied or detached phallic gaze is historically implicit ${ }^{31}$. When standing at the keyhole, Schneider notes, this historical habituation of perspective 'haunts' explicit feminist performance art and 'performance art of the explicit body in turn interrogates the prerogatives of that ghosting ${ }^{32}$.

csc - To what extent do you consider your works as self-portraits?

HW - On the one hand, my works stem from my autobiography in that they draw on my lived and embodied experiences. I equally use my body / self in the works to interrogate the cultural and social contexts related to my identity. In this sense, my works could be seen to constitute self-portraits of sorts. However, on the other hand, in their interrogation of the relations between gender, national identity and cultural history the works are not strictly or solely concerned with self-portraiture. Rather, they seek to speak more broadly to women's experiences and open up dialogue around the ways in which female bodies are policed within specific contexts, alongside retrieving radical histories that have transgressed gender norms. For example, this is pertinent within my explorations of the histories of the Magdalen Laundries or the lives of the female revolutionaries that participated in the 1916 Rising. Of course, my gestures and expressions within my works often issue an irreverent, sometimes audacious, challenging of patriarchal conventions, which is very much a personal response. However, it is equally important to me that the works remain open to broader interpretations that extend past my personal responses. Primarily, I see performance as a politicised or activist practice centred on countering gendered constructs and developing more empowered feminist discourses.

\section{NOTES}

1. Edna O'Brien, Mother Ireland, Middlesex, Penguin Books, 1976, p. 23.

2. Anne Enright, The Gathering, London, Jonathan Cape, 2007, p. 1.

3. Lois Keidan, 'What is Live Art?', Live Art Development Agency, < http:// www.thisisliveart.co.uk/about/what-is-live-art/> [Accessed January 2018].

4. Rebecca Schneider, Performing Remains: Art and War in Times of Theatrical Reenactment, London and New York, Routledge, 2011, p. 100. Emphasis in original.

5. Ibid., p. 100.

6. Ibid.

7. Ibid., p. 100. Emphasis in original.

8. Ibid., p. 103. 
9. Ruth Fletcher, 'Post-colonial Fragments: Representations of Abortion in Irish Law and Politics', Journal of Law and Society, Vol. 28(4), 2001, pp. 568-589 (p. 572).

10. Magdalena Maria Wieckiewicz writing as part of 'Right Here, Right Now - Back There, Back Then', Performance Art Live, <https://performanceartlive.weebly.com/helenawalsh-magdalena-maria-wieckiewicz-joseph-carr.html> [Accessed January 2018].

11. Kathleen M. Gough, 'Girls Interrupted: Gendered Spectres. Atlantic drag', Performance Research: A Journal of the Performing Arts, Vol. 13(4), 2008, pp. 115-126 (p. 117).

12. Margaret Kelleher, The Feminization of Famine: Expressions of the Inexpressible?, Cork, Cork University Press, 1997, p. 123.

13. Mary Condren, 'Sacrifice and Political Legitimation: The Production of a Gendered Social Order', Journal of Women's History, Vol. 6(4), 1995, pp. 160-189 (p. 162).

14. Sinéad McCoole, No Ordinary Women: Irish Female Activists in the Revolutionary Years 1900-1923, 2nd edition, Dublin, The O'Brien Press, 2015.

15. Frances Gardiner, 'Political Interest and Participation of Irish Women 1922-1992: The Unfinished Revolution', in Irish Women's Studies Reader, Ailbhe Smyth, ed., Dublin, Attic Press, 1993, pp. 45-78 (p. 51).

16. Department of the Taoiseach, Bunreacht na hÉireann / Constitution of Ireland, <">https:// www.taoiseach.gov.ie/eng/Historical_Information/The_Constitution/[Accessed January 2018].

17. Fintan Walsh, "Homelysexuality and the "Beauty" Pageant', in Crossroads: Performance Studies and Irish Culture, Sara Brady and Fintan Walsh (eds), Basingstoke, Palgrave Macmillan, 2009, pp. 196-209 (p. 197).

18. The exhibition curated by Áine Phillips and Niamh Murphy as part of the Arts Council of Ireland's centenary programme.

19. Lisa Weihman, L., 'National Treasures and Nationalist Gardens: Unlocking the Archival Mysteries of Bean na h-Éireann', Tulsa Studies in Women's Literature, Vol. 27(2), 2008, pp. 355-364, (p. 360).

20. Karen M. Steele, 'Constance Markievicz's Allegorical Garden: Femininity, Militancy, and the Press, 1909-1915’, Women's Studies, Vol. 29, 2000, pp. $423-447$ (p. 431).

21. Ibid., p. 432.

22. Ibid., p. 431.

23. Katherine Nolan, blogspot, < http://katherine-nolan.blogspot.co.uk/> [Accessed January 2018]

24. Ibid.

25. Jacqueline Belanger, 'The Laws of Metaphor: Reading Eavan Boland's Anorexic in an Irish Context', Colby Quarterly, Vol. 36(3), 2000, pp. 242-251 (p. 249).

26. Mary Condren, 'Sacrifice and Political Legitimation: The Production of a Gendered Social Order', op. cit., p. 165.

27. Rebecca Schneider, The Explicit Body in Performance, London and New York, Routledge, 1997, p. 72.

28. Ibid., p. 71.

29. Margaret Kelleher, The Feminization of Famine: Expressions of the Inexpressible?, op. cit., p. 153. 
30. Rebecca Schneider, The Explicit Body in Performance, op. cit., p. 66 -67.

31. Ibid., p. 66.

32. Ibid., p. 67.

\section{AUTHORS}

\section{CHRISTELLE SERÉE-CHAUSSINAND}

Université de Bourgogne Franche-Comté, TIL EA 4182. Christelle Serée-Chaussinand is Associate Professor at the Université de Bourgogne (Dijon) where she currently holds the position of VicePresident in charge of undergraduate and graduate levels. She teaches contemporary Irish literature, civilisation and culture. Her special research interests lie in autobiographical writings and portraiture or self-portraiture in literature as well as in the visual arts. She has published several articles on contemporary Irish literature and art, in particular on such writers and artists as Sean O'Faolain, Sebastian Barry, Derek Mahon, Paul Muldoon, Seamus Heaney, Sinéad Morrissey or Louis le Brocquy. She is a member of Centre Interlangues TIL (EA4182) and has recently run a research seminar on contemporary creation in its relation to critical theory: "Critical theory and creation: questioning images". She is a member of the editorial board of Interfaces: Texte Image Language, an international bilingual journal dedicated to intermediality / word and image.

\section{HELENA WALSH}

Helena Walsh is a live artist from Co. Kilkenny Ireland. She has been based in London since 2003. Her practice explores the relations between gender, national identity and cultural histories. Drawing on her lived and embodied experience through her work Helena seeks to positively violate the systems, borders and rules that construct gender. In 2009 she received a Doctorate Award from the Arts and Humanities Research Council (AHRC) to undertake a practice-based PhD in the Department of Drama, Queen Mary University of London, which she completed in 2013. Her doctoral research, is entitled, 'Live Art and Femininity in Post-Conflict Ireland: Between Negation and Reproduction, Rebellion and Conformity.' Helena has performed widely in galleries, museums, theatres and non-traditional art spaces, including public sites. Her current research practice is focused on the legacies of feminist activism. As part of this research, in 2016 Helena performed a new site-responsive live art work that considers the activism of the women imprisoned in Kilmainham Gaol, Dublin following the 1916 Rising in relation to contemporary tensions between nationalism and feminism. This was featured in 'Future Histories' at Kilmainham Gaol in 2016 as part of the Arts Council of Ireland's 2016 programme. 